PELÁ, A; RIBEIRO, MA; BENTO, RU; CIRINO, LHB; REIS JÚNIOR, RA. 2018. Enhanced-efficiency phosphorus fertilizer: promising technology for carrot crop. Horticultura Brasileira 36: 492-497. DOI - http://dx.doi.org/10.1590/S0102-053620180411

\title{
Enhanced-efficiency phosphorus fertilizer: promising technology for carrot crop
}

\author{
Adilson Pelá ${ }^{1}$; Matheus A Ribeiro ${ }^{1}$; Rafael U Bento ${ }^{1}$; Luiz HB Cirino ${ }^{1}$; Roberto A Reis Júnior ${ }^{2}$ \\ ${ }^{1}$ Universidade Estadual de Goiás (UEG), Ipameri-GO, Brazil; adilson.pela@ueg.br; ${ }^{2}$ WSCT, Londrina-PR, Brazil; roberto@wsct.com.br
}

\begin{abstract}
Several studies were carried out to evaluate polymer-coated mineral fertilizers; however, few studies, on the agronomic efficiency of these fertilizers in the field in carrot crop, are available. Thus, we aimed to evaluate the use of enhanced-efficiency phosphorus fertilizer coated with polymers in carrot (Daucus carota). The experiment was carried out in field, in Ipameri-GO. The experimental design was randomized blocks, arranged in an incomplete factorial design $(5 \times 2)+1$, considering five phosphorus doses $(150,300,450,600$ and $750 \mathrm{ha}^{-1} \mathrm{~kg} \mathrm{P}_{2} \mathrm{O}_{5}$ ), two P sources [conventional MAP (monoammonium phosphate) and polymer-coated MAP (Policote)] and one additional treatment (control, without P). The evaluated traits were plant height, root length, root diameter, total productivity, marketable root classes, agronomic efficiency of phosphate fertilization and $\mathrm{P}$ content in the roots. Data were submitted to analysis of variance and regression. Phosphate fertilization did not influence the $\mathrm{P}$ content in carrot roots, but increased plant height, root length and diameter and yield of carrot roots. Polymer-coated phosphate increased plant height, length, diameter and productivity of carrot roots, when compared to conventional fertilizer. Carrot productivity was, on average, $15.5 \%$ higher with polymer-coated $\mathrm{P}$ source $\left(39.42 \mathrm{tha}^{-1}\right)$ than with the conventional P source $\left(34.11 \mathrm{t} \mathrm{ha}^{-1}\right)$. Marketable roots were also improved with the use of polymer-coated phosphate fertilizer. Phosphate fertilizer coated with polymer increased the agronomic efficiency of phosphate fertilization in the carrot crop.
\end{abstract}

Keywords: Daucus carota, polymer-coated phosphorus.

\section{RESUMO}

Fertilizante fosfatado de eficiência aumentada: uma tecnologia promissora na cultura da cenoura

Existem diversos estudos para avaliação das características químicas dos fertilizantes minerais recobertos por polímeros, porém, são escassas as pesquisas que avaliam a eficiência agronômica dos mesmos a campo na cultura da cenoura. Dessa forma, objetivou-se avaliar o uso de fertilizante fosfatado de eficiência aumentada (Policote) na cultura da cenoura (Daucus carota). O trabalho foi realizado em condições de campo no município de Ipameri-GO. O delineamento experimental foi de blocos ao acaso, arranjados em esquema fatorial $(5 \times 2)+1$, sendo cinco doses de fósforo $\left(150,300,450,600\right.$ e $750 \mathrm{ha}^{-1} \mathrm{~kg}$ de $\left.\mathrm{P}_{2} \mathrm{O}_{5}\right)$, duas fontes de $\mathrm{P}$ \{MAP (monoamonio fosfato) convencional e MAP revestido por polímero $\}$ além de um tratamento adicional (testemunha, sem P). Foram avaliados a altura de plantas, comprimento e diâmetro de raiz, além da produtividade total e classes comerciais das raízes, eficiência agronômica da adubação fosfatada e teor de $\mathrm{P}$ nas raízes. Os dados foram submetidos à análise de variância e regressão. A adubação fosfatada não influenciou o teor de $\mathrm{P}$ nas raízes da cenoura, mas aumentou a altura de plantas, o comprimento, o diâmetro e a produtividade de raízes de cenoura. $\mathrm{O}$ adubo fosfatado revestido com polímero aumentou a altura de plantas, o comprimento e a produtividade de raízes de cenoura, em relação ao adubo sem revestimento. A produtividade de cenoura foi, em média, $15,5 \%$ maior com a fonte de $\mathrm{P}$ revestida $\left(39,42 \mathrm{t} \mathrm{ha}^{-1}\right)$, em relação à fonte convencional $\left(34,11 \mathrm{t} \mathrm{ha}^{-1}\right)$. Também verificou-se melhoria nos padrões comerciais das raízes com a utilização do adubo fosfatado revestido. O revestimento do adubo fosfatado com o polímero da marca Policote aumentou a eficiência agronômica da adubação fosfatada na cultura da cenoura.

Palavras-chave: Daucus carota, Policote, fósforo.

\section{Received on February 17, 2017; accepted on October 13, 2018}

$\mathrm{C}$ arrot (Daucus carota) is the main root vegetable in terms of economic value and it is among the ten most cultivated vegetable crops in Brazil, with a consumption of $5.8 \mathrm{~kg} /$ person/year (Zanfirov et al., 2012). The estimated production of this vegetable in the country is about $752,000 \mathrm{t}$, in 2016, being the fourth most important vegetable considering the quantity marketed in the distribution center and the fifth most important crop, economically speaking; the market totaled 153.83 million dollars (CNA, 2017).

Carrot is a demanding vegetable in relation to nutrition, especially due to its short vegetative cycle and high production of dry mass (Filgueira, 2013). Some studies carried out in
Brazil showed that the decreasing order of macronutrients extracted by carrot crops is potassium, nitrogen, calcium, phosphorus, sulfur and magnesium (Luz et al., 2009). Even phosphorus being the $4^{\text {th }}$ element extracted by the carrot crop, is one of the elements which is the most used (high doses), in fertilization program for carrots. $\mathrm{P}$ is well known as being one of the most important elements 
for plant metabolism, being essential for establishment and development of the plants (Silva et al., 2015), since it favors the root system, increasing the absorption of water and nutrients, resulting in an increase of this vegetable productivity (Avalhaes et al., 2009).

$\mathrm{P}$ is widely used for fertilization since it is one of the most limiting nutrients for agricultural crops, mainly in tropical soil rich in iron and aluminum oxides (Araújo, 2011). "Free" Fe, the amount of aluminum replacing iron and, in lower quantities, "amorphous" Fe and kaolinite are the main responsible elements for phosphorus fixation (Santos et al., 2008), determining the low efficiency of phosphate fertilizers (Wang et al., 2010). According to Novais et al. (2007), the deficiency of $\mathrm{P}$ is one of the main reasons for the low agricultural production in most Brazilian soils.

In acid soils such as Cerrado soil, P content is limiting, and $\mathrm{P}$ fertilizations show low efficiency due to its large adsorption on soil mineral phase, predominantly of low reversibility, mainly in $\mathrm{Fe}$ and $\mathrm{Al}$ oxides (Schoninger $e t$ al., 2013). Thus, phosphate fertilization is a high-cost investment, characterized by great amounts of P used (Gazola et al., 2013). The situation becomes worse due to the fact that phosphate is a non-renewable natural resources, it is also scarce and without substitutes, and should, therefore, be efficiently used (Lana, 2009).

Among the alternatives to increase the best use of phosphate fertilizers, the use of enhanced-efficiency fertilizers (EEFs) stands out. These fertilizers reduce nutrient loss to the environment and increase nutrient availability to the plants. EEFs are divided in two groups: slow and controlled-release and stabilized. Recently, additives with greater affinity for iron and aluminum than phosphorus, such as the Policote brand, have been used for coating phosphate fertilizers to produce stabilized EEFs, aiming to reduce $P$ fixation rate and availability of the nutrient in soil. Policote is a soluble anionic polymer with $93.7 \%$ biodegradability (Chagas et al., 2015). However, since it is a new technology available for agriculture, studies in order to prove agronomic efficiency, mainly on more demanding crops, like vegetables, such as carrots, are necessary.

This study aimed to evaluate the efficiency of phosphorus source coating with Policote brand polymer (enhancedefficiency fertilizer) in development, quality and productivity of carrot crop.

\section{MATERIAL AND METHODS}

The experiment was installed at the experimental farm of Universidade Estadual de Goiás, Ipameri Campus (1704306"S, 48 $\left.08^{\prime} 39^{\prime \prime} \mathrm{W}\right)$, in a RedYellow Oxisols, medium texture (Santos et al., 2013). Soil chemical analysis of this area was done before the experiment installation, in the $0-20 \mathrm{~cm}$ layer. The results obtained were: $\mathrm{pH}=6.1 ; \mathrm{P}$ (Mehlich) $=4.0 \mathrm{mg} \mathrm{dm}^{-3} ; \mathrm{K}=140.0 \mathrm{mg}$ $\mathrm{dm}^{-3} ; \mathrm{H}+\mathrm{Al}=14.0 \mathrm{mmol}_{\mathrm{c}} \mathrm{dm}^{-3} ; \mathrm{Al}^{3+}=$ $0.0 \mathrm{mmol}_{\mathrm{c}} \mathrm{dm}^{-3} ; \mathrm{Ca}=17.0 \mathrm{mmol}_{\mathrm{c}} \mathrm{dm}^{-3}$; $\mathrm{Mg}=9.0 \mathrm{mmol}_{\mathrm{c}} \mathrm{dm}^{-3}$; organic matter $18.0 \mathrm{~g} \mathrm{dm}^{-3} ; \mathrm{CEC}=43.6 \mathrm{mmol}_{\mathrm{c}} \mathrm{dm}^{-3}$; clay, silt and sand of 350, 100 and 550 $\mathrm{g} \mathrm{kg}^{-1}$, respectively, and base saturation, 67.9\%. P availability (Mehlich), in soil, was classified as "very low" according to Ribeiro et al. (1999). Conventional soil preparation was carried out using two harrowing, and leveling.

The experimental design consisted of randomized blocks, arranged in an incomplete factorial design $(5 \times 2)+1$, considering five doses of phosphorus ( $\mathrm{MAP}=$ monoammonium phosphate) $\left(150,300,450,600\right.$ and $750 \mathrm{~kg} \mathrm{ha}^{-1}$ $\mathrm{P}_{2} \mathrm{O}_{5}$ ), two P sources (conventional MAP and polymer-coated MAP) and one additional treatment (control without P), with four replicates.

The experimental plot consisted of six double rows, spaced $0.10 \mathrm{~m}$ between the double rows and $0.35 \mathrm{~m}$ between the centrals, measuring 3 meters length. The authors considered useful area the four central rows, discarding $0.50 \mathrm{~m}$ of each end, resulting in a useful area of $1.80 \mathrm{~m}^{2}$. Hybrid cultivar Juliana (700,000 plants $\mathrm{ha}^{-1}$ ) was manually sown on September 1, 2015, after being fertilized with $60 \mathrm{~kg}$ $\mathrm{N}+400 \mathrm{~kg} \mathrm{ha}^{-1} \mathrm{~K}_{2} \mathrm{O}$, using urea and $\mathrm{KCl}$ as sources, respectively, and application of treatments in the sowing furrow. In order to avoid competition among plants, thinning was done 30 days after planting, spaced $3 \mathrm{~cm}$ between plants. Top dressing was performed applying 60 $\mathrm{kg} \mathrm{ha}^{-1}$ of $\mathrm{N}$ in all treatments, using urea as source, 45 days after planting.

Pest and disease were controlled preventively spraying insecticides from the following chemical products: benzoylurea, neonicotinoid and pyrethroid, and fungicides of the chemical groups: benzimidazole, isophthalonitrile, acetamide, phenylamide and strobilurins. The range of application rate, recommended by the manufacturer, and also the visual diagnosis were the criteria for application.

Plants were harvested 110 days after planting; plant height and root length were evaluated using a measuring tape, root diameter with the aid of a digital caliper and root productivity. After harvest, two roots per plot were sampled in order to determine phosphorus content. Roots were properly washed and dried in forced air circulation until reaching constant mass $\left(70^{\circ} \mathrm{C}\right)$; then, they were ground using a Willey type mill. Afterwards, the roots were digested with $1 \mathrm{M} \mathrm{HCl}$ in water bath at $80^{\circ} \mathrm{C}$ (Miyazawa et al., 1992) and $\mathrm{P}$ content was determined by reading in induced plasma atomic emission spectrophotometry (ICP- AES).

Roots were classified through average root length, according to the classes proposed by Hortbrasil (2009), in which carrots shorter than $10 \mathrm{~cm}$ long are considered unmarketable; class 10 included roots measuring $10 \leq 14 \mathrm{~cm}$; class 14 , roots measuring $14 \leq 18 \mathrm{~cm}$; class 18 roots measuring $18 \leq 22 \mathrm{~cm}$; class 22 , measuring $22 \leq 26 \mathrm{~cm}$; and class 26 roots longer than $26 \mathrm{~cm}$.

Using the average productivity data, the authors calculated the Agronomic Efficiency Index of Phosphorus (IEAP) observed in the evaluated sources, using the equation described by Fageria et al. (2012):

IEAP $=$ (productivity with phosphorus, in $\mathrm{kg} \mathrm{ha}^{-1}$ - productivity without phosphorus, in $\mathrm{kg} \mathrm{ha}^{-1}$ ) / (applied dose of $\mathrm{P}_{2} \mathrm{O}_{5}$, in kg ha-1)

Data were submitted to $F$ test (variance and regression analysis) for effects of $\mathrm{P}$ 
rates, at $5 \%$ probability.

\section{RESULTS AND DISCUSSION}

All treatments were superior when compared to the control, for all evaluated variables, except for $\mathrm{P}$ content of roots (Table 1). Interaction between sources and doses did not show any significant differences, for all the evaluated variables, either. $\mathrm{F}$ test was significant for plant height, length and diameter of the roots and crop productivity were influenced both by sources and by doses, except for the effect of source on root diameter.
$\mathrm{P}$ content in roots was not significantly influenced by phosphate fertilization, showing average values of 4.58 and $4.89 \mathrm{~g} \mathrm{~kg}^{-1}$ for MAP and polymer-coated MAP, respectively (Table 1). These $\mathrm{P}$ contents are higher than the ones observed by Ribeiro Filho et al. (2011) evaluating carrot roots at 120 days after planting $\left(3.27 \mathrm{~g} \mathrm{~kg}^{-1}\right)$.

Plant height increased with doses of $\mathrm{P}$ and it was significantly different among phosphorus sources (Table 1). The average plant height observed with polymer-coated MAP (56.60 $\mathrm{cm})$ was $9.86 \%$ higher than the plant height verified with MAP $(51.52 \mathrm{~cm})$. Significant response was also noticed for doses of $\mathrm{P}$ with quadratic adjustments for both sources (Figure 1a). Using MAP as a source, plant height increased from $34.5 \mathrm{~cm}$, without phosphate fertilization, up to maximum value of $55.5 \mathrm{~cm}$, with dose of $566.5 \mathrm{~kg} \mathrm{ha}^{-1} \mathrm{P}_{2} \mathrm{O}_{5}$. However, when using polymer-coated MAP as a source, plant height increased from 38.0 $\mathrm{cm}$, without phosphate fertilization, up to maximum value of $60.1 \mathrm{~cm}$, with the dose of $515.6 \mathrm{~kg} \mathrm{ha}^{-1} \mathrm{P}_{2} \mathrm{O}_{5}$. The maximum plant height observed using the polymer-coated MAP as a source was $8.28 \%$ higher than the maximum plant height observed with MAP, using $8.98 \%$ less phosphorus $\left(\mathrm{kg} \mathrm{ha}^{-1} \mathrm{P}_{2} \mathrm{O}_{5}\right)$.

Phosphate fertilization increased significantly root length (CR), considering that this trait was

Table 1. F-test results for phosphorus content of the roots (TP), plant height (AP), root length (CR), root diameter (DR) and carrot productivity (Prod) as well as averages and coefficients of variation observed in analysis of variance. Ipameri, UEG, 2016.

\begin{tabular}{|c|c|c|c|c|c|}
\hline Treatments & TP $(\mathrm{g} / \mathrm{kg})$ & $\mathrm{AP}(\mathrm{cm})$ & $\mathrm{CR}(\mathrm{cm})$ & DR (cm) & Prod (t/ha) \\
\hline Control $\left(000 \mathrm{~kg} \mathrm{ha}^{-1} \mathrm{P}_{2} \mathrm{O}_{5}\right)$ & 4.32 & 35.02 & 12.18 & 218 & 17.04 \\
\hline $\operatorname{MAP}\left(150 \mathrm{~kg} \mathrm{ha}^{-1} \mathrm{P}_{2} \mathrm{O}_{5}\right)$ & 4.27 & 42.68 & 15.35 & 257 & 20.80 \\
\hline $\operatorname{MAP}\left(300 \mathrm{~kg} \mathrm{ha}^{-1} \mathrm{P}_{2} \mathrm{O}_{5}\right)$ & 4.92 & 51.86 & 17.37 & 326 & 30.68 \\
\hline MAP $\left(450 \mathrm{~kg} \mathrm{ha}^{-1} \mathrm{P}_{2} \mathrm{O}_{5}\right)$ & 4.81 & 54.34 & 17.79 & 340 & 37.16 \\
\hline $\operatorname{MAP}\left(600 \mathrm{~kg} \mathrm{ha}^{-1} \mathrm{P}_{2} \mathrm{O}_{5}\right)$ & 4.61 & 55.59 & 19.02 & 365 & 42.60 \\
\hline $\operatorname{MAP}\left(750 \mathrm{~kg} \mathrm{ha}^{-1} \mathrm{P}_{2} \mathrm{O}_{5}\right)$ & 4.28 & 53.12 & 17.51 & 356 & 39.30 \\
\hline $\mathrm{MAP}+$ Policote $\left(150 \mathrm{~kg} \mathrm{ha}^{-1} \mathrm{P}_{2} \mathrm{O}_{5}\right)$ & 4.09 & 54.21 & 17.31 & 317 & 32.37 \\
\hline $\mathrm{MAP}+$ Policote $\left(300 \mathrm{~kg} \mathrm{ha}^{-1} \mathrm{P}_{2} \mathrm{O}_{5}\right)$ & 5.17 & 56.51 & 18.21 & 322 & 35.49 \\
\hline $\mathrm{MAP}+$ Policote $\left(450 \mathrm{~kg} \mathrm{ha}^{-1} \mathrm{P}_{2} \mathrm{O}_{5}\right)$ & 4.88 & 57.11 & 18.96 & 358 & 39.86 \\
\hline $\mathrm{MAP}+$ Policote $\left(600 \mathrm{~kg} \mathrm{ha}^{-1} \mathrm{P}_{2} \mathrm{O}_{5}\right)$ & 5.19 & 57.87 & 19.44 & 377 & 45.15 \\
\hline $\mathrm{MAP}+$ Policote $\left(750 \mathrm{~kg} \mathrm{ha}^{-1} \mathrm{P}_{2} \mathrm{O}_{5}\right)$ & 5.13 & 57.30 & 18.84 & 362 & 44.20 \\
\hline \multicolumn{6}{|l|}{ Average doses } \\
\hline MAP & 4.58 & $51.52 b$ & $17.41 b$ & 329 & $34.11 b$ \\
\hline MAP+Policote & 4.89 & $56.60 \mathrm{a}$ & $18.55 \mathrm{a}$ & 347 & $39.42 \mathrm{a}$ \\
\hline \multicolumn{6}{|l|}{ Average source } \\
\hline $000 \mathrm{~kg} \mathrm{ha}^{-1} \mathrm{P}_{2} \mathrm{O}_{5}$ & 4.32 & 35.02 & 12.18 & 218 & 17.04 \\
\hline $150 \mathrm{~kg} \mathrm{ha}^{-1} \mathrm{P}_{2} \mathrm{O}_{5}$ & 4.18 & 48.45 & 16.33 & 287 & 26.59 \\
\hline $300 \mathrm{~kg} \mathrm{ha}^{-1} \mathrm{P}_{2} \mathrm{O}_{5}$ & 5.05 & 54.18 & 17.79 & 324 & 33.09 \\
\hline $450 \mathrm{~kg} \mathrm{ha}^{-1} \mathrm{P}_{2} \mathrm{O}_{5}$ & 4.84 & 55.72 & 18.38 & 349 & 38.51 \\
\hline $600 \mathrm{~kg} \mathrm{ha}^{-1} \mathrm{P}_{2} \mathrm{O}_{5}$ & 4.90 & 56.73 & 19.23 & 371 & 43.87 \\
\hline $750 \mathrm{~kg} \mathrm{ha}^{-1} \mathrm{P}_{2} \mathrm{O}_{5}$ & 4.70 & 55.21 & 18.17 & 359 & 41.75 \\
\hline \multirow[t]{2}{*}{ General average } & 4.70 & 52.33 & 17.45 & 327 & 34.97 \\
\hline & \multicolumn{5}{|c|}{ Calculated F (anova) } \\
\hline Additional treatment & $0.96^{\mathrm{ns}}$ & $106.48 * *$ & $139.07 * *$ & $61.90 * *$ & $33.41 * *$ \\
\hline Source & $1.47^{\mathrm{ns}}$ & $20.85^{* *}$ & $14.81 * *$ & $3.85^{\mathrm{ns}}$ & $6.65^{*}$ \\
\hline Dose & $1.35^{\mathrm{ns}}$ & $6.90 * *$ & $10.25^{* *}$ & $10.44 * *$ & $9.23 * *$ \\
\hline Source*Dose & $0.51^{\mathrm{ns}}$ & $2.25^{\mathrm{ns}}$ & $0.74^{\mathrm{ns}}$ & $1.42^{\mathrm{ns}}$ & $0.63^{\mathrm{ns}}$ \\
\hline $\mathrm{CV}(\%)$ & 17.2 & 6.72 & 5.38 & 8.92 & 18.61 \\
\hline
\end{tabular}

$\mathrm{ns}=$ non-significant; ${ }^{*}=\mathrm{p}<0.05 ;{ }^{* *}=\mathrm{p}<0.01$. Average followed by same letters are statistically equal among each other $(\mathrm{F}$ test). 
significantly different among $\mathrm{P}$ sources (Table 1). The average of CR observed, using the polymer-coated MAP (18.55 $\mathrm{cm})$, was $6.5 \%$ higher than CR observed using MAP (17.41 cm). In the absence of phosphate fertilization, the average of CR was $12.18 \mathrm{~cm}$, resulting in class 10 carrots, according to Hortbrasil (2009). Using MAP as source, carrot classification, based on the average of $\mathrm{CR}$, was 14 , whereas it was 18 using the

polymer-coated MAP. Thus, phosphate fertilization and coated fertilizer (using Policote) improved the classification of the carrot, since $P$ participates in several metabolic processes such as respiration, photosynthesis, cell division, storage and energy transfer (Taiz \& Zeiger, 2013) favoring the development of root system (Araújo et al., 2004).

CR also showed significant quadratic adjustments in relation to doses of $\mathrm{P}$,

Table 2. Agronomic efficiency indexes observed between sources and doses of phosphorus in production of carrot roots (MAP= monoammonium phosphate). Ipameri, UEG, 2016.

\begin{tabular}{lccc}
\hline Doses of P & MAP & MAP+Policote & Average \\
\hline 150 & 25.10 & 102.25 & 63.68 \\
300 & 45.48 & 61.53 & 53.50 \\
450 & 44.73 & 50.73 & 47.73 \\
600 & 42.61 & 46.85 & 44.73 \\
750 & 29.68 & 36.22 & 32.95 \\
\hline Average & 37.52 & 59.52 & - \\
\hline
\end{tabular}

for both sources (Figure 1b). Using conventional MAP, CR increased from $12.2 \mathrm{~cm}$, in the absence of phosphate fertilization, up to the maximum value of $19.7 \mathrm{~cm}$, with the dose of $535.2 \mathrm{~kg}$ $\mathrm{ha}^{-1} \mathrm{P}_{2} \mathrm{O}_{5}$. The longest roots observed using the polymer coated MAP was $6.5 \%$ longer than the one observed using conventional MAP, using 2.15\% less phosphorus. The authors also noticed that standard CR for hybrid carrot cultivar Juliana (18-22 cm) was obtained with lower doses of $\mathrm{P}$ when using polymer-coated MAP as a source. CRs observed in this study were higher than CRs observed by Ribeiro Filho et al. (2011).

Root diameter (DR) was significantly influenced by doses of $\mathrm{P}$; the same was not verified among sources of phosphorus. Figure 2a shows an increase of DR with phosphate fertilization. DR increased from $2.20 \mathrm{~cm}$, in the absence of phosphate fertilization, up to 3.65 ,

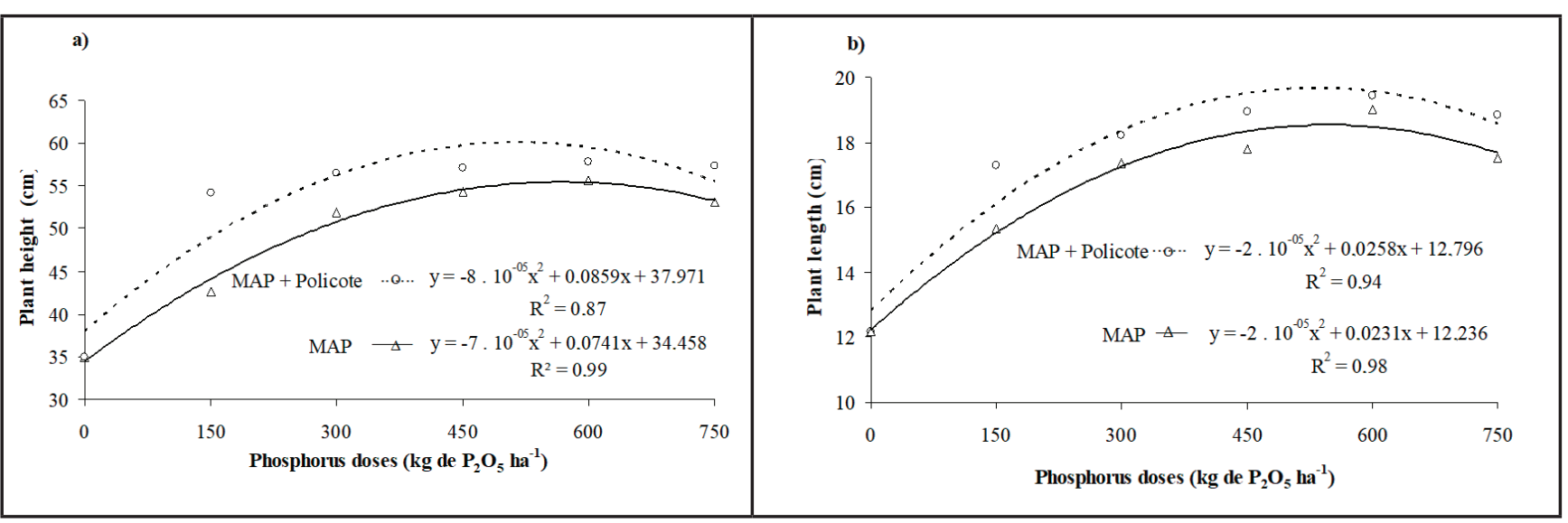

Figure 1. Plant height (a) and carrot root length (b) in harvest in response to sources and doses of phosphorus. Ipameri, UEG, 2016.
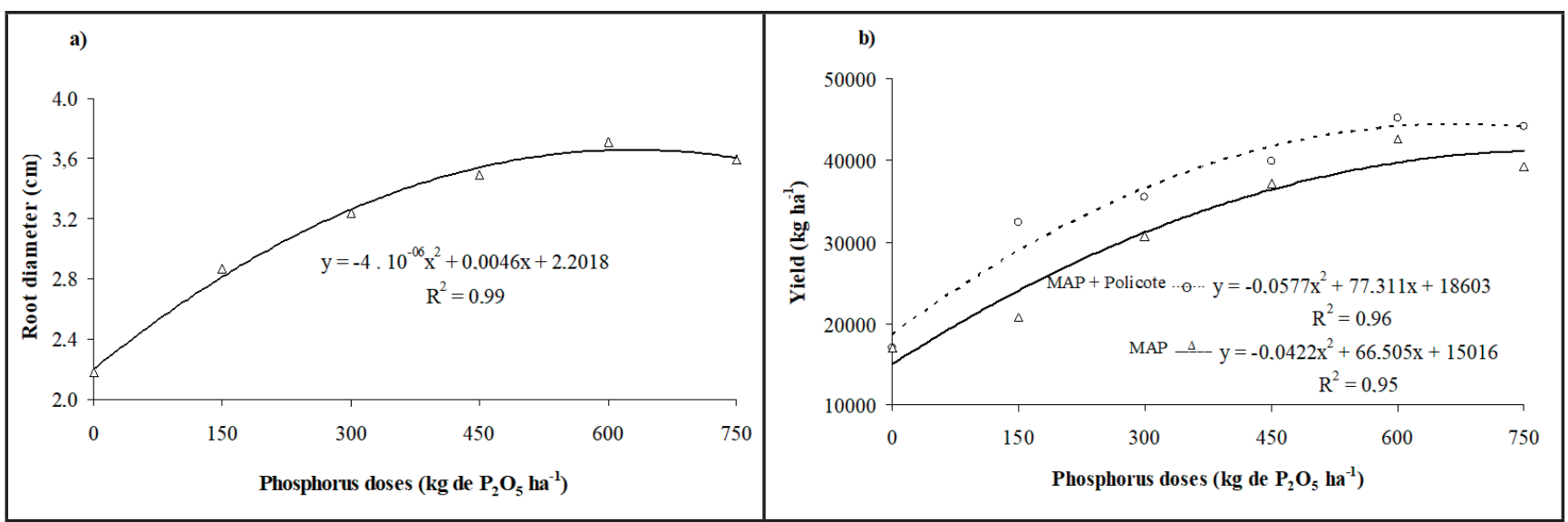

Figure 2. Root diameter (a) and productivity (b) of carrot in response to doses of P. Ipameri, UEG, 2016. Ipameri, UEG, 2016. 
with dose of $628.7 \mathrm{~kg} \mathrm{ha}^{-1} \mathrm{P}_{2} \mathrm{O}_{5}$.

Phosphate fertilization significantly increased carrot productivity, which was also significantly influenced by $\mathrm{P}$ sources (Figure 2b). Araújo et al. (2004) also verified an increase of carrot productivity with phosphate fertilizer, and by the residual effect of doses up to $762.5 \mathrm{~kg} \mathrm{ha}^{-1} \mathrm{P}_{2} \mathrm{O}_{5}$ and organic waste compost by Mesquita Filho et al. (2002). The maximum productivities observed in this study with phosphate fertilizer were higher than the national average reported by Santos et al. (2015), 31.0 $\mathrm{t} \mathrm{ha}^{-1}$, in 2014. Average productivity, using polymer-coated phosphate fertilization (39.41 $\left.\mathrm{t} \mathrm{ha}^{-1}\right)$, was $15.5 \%$ higher than the productivity observed with conventional phosphate fertilizer (34.11 tha $\mathrm{th}^{-1}$ ). Using MAP as source, the maximum carrot productivity $(41.34 \mathrm{t}$ $\mathrm{ha}^{-1}$ ) was observed with a dose of 791.7 $\mathrm{kg} \mathrm{ha}^{-1} \mathrm{P}_{2} \mathrm{O}_{5}$, whereas with polymercoated MAP, the maximum carrot productivity $\left(44.49 \mathrm{t} \mathrm{ha}^{-1}\right)$ was observed with a dose of $669.8 \mathrm{~kg} \mathrm{ha}^{-1} \mathrm{P}_{2} \mathrm{O}_{5}$. This means that when using polymer-coated MAP, the authors observed an increase of $7.6 \%$ in maximum productivity, with phosphate fertilization $15.4 \%$ lower than the one used with conventional fertilization. Productivity value of 41.34 $\mathrm{t} \mathrm{ha}^{-1}$ was reached with $791.7 \mathrm{~kg} \mathrm{ha}^{-1}$ $\mathrm{P}_{2} \mathrm{O}_{5}$, using polymer-coated MAP as source. In other words, when polymercoated MAP was used, $54.1 \%$ of the dose used via MAP was enough for the same productivity. This behavior may be attributed to the higher $P$ availability over time, in relation to the lowest fixation rate, mainly in Red-Yellow Oxisols (Machado \& Souza, 2012).

With increasing doses of $\mathrm{P}$, a reduction in agronomic efficiency of phosphorus (IEAP) was noticed, which can be explained by the law of decreasing increments (Table 2). In all doses of $\mathrm{P}$, the authors observed higher IEAP when using polymer-coated MAP. In average, polymer coating increased IEAP in $58.6 \%$.

Phosphate fertilization did not influence $\mathrm{P}$ content in carrot roots, increased plant height, length, diameter and root productivity, though.

Polymer-coated phosphate fertilization increased plant height, length and root productivity, in relation to conventional fertilization.

Carrot productivity was, in average, $15.5 \%$ higher using polymercoated source Policote, compared to conventional source. In order to reach maximum productivity, 791.7 $\mathrm{kg} \mathrm{ha}^{-1} \mathrm{P}_{2} \mathrm{O}_{5}$ of conventional MAP and $669.8 \mathrm{~kg} \mathrm{ha}^{-1} \mathrm{P}_{2} \mathrm{O}_{5}$ of polymer-coated MAP were necessary. The authors also verified an improvement in marketable root standards, in relation to an increase of root length, using polymer-coated phosphate fertilization.

Under soil and weather conditions in this study, phosphorus source coating with Policote brand polymer increased the agronomic efficiency of phosphate fertilization for carrot crop. Considering the positive results, new experiments, under other soil and weather conditions, and using other carrot cultivars are important to build data bank which allows to build a table to recommend polymer-coated phosphate fertilization.

\section{ACKNOWLEDGMENTS}

To Universidade Estadual de Goiás for giving the productivity scholarship (PROBIP 2016) to the first author.

\section{REFERENCES}

ARAÚJO, FF. 2011. Disponibilização de fósforo, correção do solo, teores foliares e rendimento de milho após a incorporação de fosfatos e lodo de curtume natural e compostado. Acta Scientiarum. Agronomy 33: 355-360.

ARAUJO, C; ZÁRATE, NAH; VIEIRA, MC. 2004. Produção e perda de massa pós-colheita de cenoura 'Brasília', considerando doses de fósforo e de cama de frango semi decomposta. Acta Scientiarum. Agronomy 26: 131-138.

AVALHAES, CC; PRADO, RM; GONDI, ARO; ALVES, AU; CORREIA, MAR. 2009. Rendimento e crescimento da beterraba em função da adubação com fósforo. Scientia Agrária 10: 75-80.

CHAGAS, WFT; EMRICH, EB; GUELFI, DR; CAPUTO, ALC; FAQUIN, V. 2015. Productive characteristics, nutrition and agronomic efficiency of polymer-coated MAP in lettuce crop. Revista Ciência Agronômica 46: 266-276.

CNA. 2017. Mapeamento e quantificação da cadeia produtiva de hortaliças. Brasília:
Confederação da Agricultura e Pecuária do Brasil. 72p.

FAGERIA, NC; SANTOS, AB; STONE, LF. 2012. Eficiência do uso de fósforo por genótipos de arroz irrigado. Embrapa Arroz e Feijão. Available at $<$ http://ainfo.cnptia.embrapa. br/digital/bitstream/item/59467/1/107.pdf $>$ Accessed February 12, 2015.

FILGUEIRA, FAR. 2013. Novo manual de olericultura: agrotecnologia moderna na produção e comercialização de hortaliças. 3 . ed. rev. amp. Viçosa: UFV, 421p.

HORTBRASIL. 2009. Normas de classificação impressas pelo Programa Brasileiro para a Modernização da Horticultura: cenoura. Available at <http://www.hortibrasil.org. br/2016-06-02-10-49-06.html>. Accessed October 18, 2015.

GAZOLA, RN; BUZETTI, S; DINALLI, RP; TEIXEIRA FILHO, MCM; CELESTRINO, TS. 2013. Efeito residual da aplicação de fosfato monoamônico revestido por diferentes polímeros na cultura do milho. Revista Ceres 60: 876-884.

LANA, RP. 2009. Uso racional de recursos naturais não-renováveis: aspectos biológicos, econômicos e ambientais. Revista Brasileira de Zootecnia 38: 330-340.

LUZ, JMQ; ZORZAL FILHO, A; RODRIGUES, WL; RODRIGUES, CR; QUEIROZ, AA. 2009. Adubação de cobertura com nitrogênio, potássio e cálcio na produção comercial de cenoura. Horticultura Brasileira 27: 543-548.

MACHADO, VJ; SOUZA, CHE. 2012. Disponibilidade de fósforo em solos com diferentes texturas após aplicação de doses crescentes de fosfato monoamônico de liberação lenta. Bioscience Journal 28: 1-7.

MESQUITA FILHO, MV; SOUZA, AF; MOITA, AW; RAMAGEM, RD. 2002. Produção comercializável e teores de $\mathrm{Cu}$ e $\mathrm{Zn}$ em cenoura em decorrência da ação residual de fósforo e composto de lixo em solo sob cerrado. Horticultura Brasileira 20: 153-157.

MIYAZAWA, M; PAVAN, MA; BLOCH, MF. 1992. Análise química de tecido vegetal. Londrina: IAPAR. 17p. (Circular, 74).

NOVAIS, RF; SMYTH, TJ; NUNES, FN. 2007. Fósforo. In: NOVAIS, RF; ALVAREZ, VVH; BARROS, NF; FONTES, RLF; CANTARUTTI, RB; NEVES, JCL (eds). Fertilidade do solo. Viçosa: SBCS. p. 471-550.

RIBEIRO, AC; GUIMARÃES, PTG; ALVAREZ, VVH. 1999. Recomendações para o uso de corretivos e fertilizantes em Minas Gerais: $5^{a}$ aproximação. Viçosa: Comissão de Fertilidade do solo do Estado de Minas Gerais. 360p.

RIBEIRO FILHO, NM; FLORÊNCIO, IM; BRITO, AC; DANTAS, JP; CAVALCANTI, MT. 2011. Avaliação nutricional de raízes de faveleira e cenoura em períodos equidistantes de coleta. Revista Brasileira de Produtos Agroindustriais 13: 169-175.

SANTOS, CE; KIST, BB; CARVALHO, C; REETZ, ER; MÜLLER ,I; BELING, RR; POLL H. 2015. Anuário brasileiro de hortaliças 2015. Santa Cruz do Sul: Editora Gazeta. 68p. 
SANTOS, DR; GATIBONI, LC; KAMINSKI, J. 2008. Fatores que afetam a disponibilidade do fósforo e o manejo da adubação fosfatada em solos sob sistema plantio direto. Ciência Rural 38: 576-586.

SANTOS, HG; JACOMINE, PKT; ANJOS, LHC; OLIVEIRA, VA; LUMBRERAS, JF; COELHO, MR; ALMEIDA, JA; CUNHA, TJF; OLIVEIRA, JB. 2013. Sistema brasileiro de classificação de solos. 3. ed. rev. e ampl.
Brasília: Embrapa. 353p.

SILVA, JTA; SIMAO, FR; ALVES, JJM. 2015. Vegetative development and production of Jatropha in response to phosphorus fertilization. Revista Ceres 62: 319-322.

SCHONINGER, EL; GATIBONI, LC; ERNANI, PR. 2013. Fertilização com fosfato natural e cinética de absorção de fósforo de soja e plantas de cobertura do cerrado. Semina: Ciências Agrárias 34: 95-106.
TAIZ, L; ZEIGER, E. 2013. Fisiologia vegetal $5^{\mathrm{a}}$ ed. Porto Alegre: Artmed. 918p.

ZANFIROV, CA; CORREA, CV; CARPANETTI, MG; CORREA, FF; CARDOSO, AII. 2012. Produção de cenoura em função das doses de potássio em cobertura. Horticultura Brasileira 30: 747-750.

WANG, X; SHEN, J; LIAO, H. 2010. Acquisition or utilization which is more critical for enhancing phosphorus efficiency in modern crops? Plant Science 179: 302-306. 